\title{
Possibilities of educational technologies for forming the physical activity-related health competence of students in the course of distance learning
}

\author{
Possibilidades de tecnologias educativas para a formação da \\ competência em saúde relacionada à atividade física de estudantes no \\ curso de EAD
}

\section{Posibilidades de las tecnologías educativas para formar la competencia en salud relacionada con la actividad física de los estudiantes en el curso de educación a distancia}

\author{
Lidiia Pavlovna Mokrova1 ${ }^{1}$, Irina Vladimirovna Evgrafova² ${ }^{\text {iD }}$, \\ Tatiana Vladimirovna Bogdanova3 ${ }^{\text {iD }}$, Antonina Vakulenko4 iD, \\ Oksana Alekseevna Konnova5 ${ }^{5}$
}

\footnotetext{
${ }^{1}$ Financial University under the Government of the Russian Federation, Moscow, Russia.

${ }^{2}$ State Marine Technical University of Saint-Petersburg, Saint-Petersburg, Russia.

${ }^{3}$ Saint-Petersburg State Marine Technical University, Saint-Petersburg, Russia.

${ }^{4}$ Moscow State University of Management Technologies named after K. G. Razumovsky (PKU), Russia.

${ }^{5}$ Russian State University of Tourism and Service, Moscow, Russia.
}

Corresponding author:

Lidiia Pavlovna Mokrova

Email: Mokrova_L@mail.ru

How to cite: Mokrova, L. P., Evografova, I. V., Boadanova, T. V., Vakulenko, A., \& Konnova, O. A. (2022). Possibilities of educational technologies for forming the physical activity-related health competence of students in the course of distance learning. Revista Tempos e Espaços em Educação, 15(34), e17297.

http://dx.doi.org/10.20952/revtee.v14i33.17297

\begin{abstract}
Youth's health is currently considered at the level of universities: various programs and projects are implemented; teaching aids and methodological recommendations are introduced into the educational process. All this requires the development and use of new educational technologies to form the values-based attitude of students to their health. Due to the COVID-19 outbreak, the heads of many universities had to make a difficult decision to suspend the educational activities of their students, which requires quick adaptation to the new conditions. The study aims at determining the readiness of students to form physical activity-related health competence in the course of distance learning. The article provides an experimental assessment of students' readiness to form the physical activity-related health competence in the course of distance learning. The lack of it
\end{abstract}


stipulates the need to determine specific activities to improve distance learning in physical education and sports. Consequently, the current need is to form the physical activity-related health competence of students, which ensures the improvement of their health and the possibility of realizing their potential abilities in the learning process.

Keywords: COVID-19. Physical activity-related health competence. Distance learning. Independent work.

\section{RESUMO}

A saúde do jovem é atualmente considerada ao nível das universidades: vários programas e projetos são implementados; auxiliares de ensino e recomendações metodológicas são introduzidos no processo educacional. Tudo isso requer o desenvolvimento e uso de novas tecnologias educacionais para formar a atitude baseada em valores dos alunos em relação à sua saúde. Devido ao surto de COVID-19, os diretores de muitas universidades tiveram que tomar uma difícil decisão de suspender as atividades educacionais de seus alunos, o que exige uma rápida adaptação às novas condições. $\mathrm{O}$ estudo tem como objetivo determinar a prontidão dos alunos para formar competências em saúde relacionadas à atividade física no curso de ensino a distância. $\mathrm{O}$ artigo fornece uma avaliação experimental da prontidão dos alunos para formar a competência em saúde relacionada à atividade física no curso de ensino a distância. A falta dele estipula a necessidade de determinar atividades específicas para melhorar o ensino a distância na educação física e no esporte. Consequentemente, a necessidade atual é formar a competência em saúde relacionada à atividade física dos alunos, o que garante a melhoria de sua saúde e a possibilidade de realizar suas habilidades potenciais no processo de aprendizagem.

Palavras-chave: COVID-19. Competência em saúde relacionada à atividade física. Ensino à distância. Trabalho independente.

\section{RESUMEN}

La salud de los jóvenes se considera actualmente a nivel de las universidades: se implementan diversos programas y proyectos; Se introducen en el proceso educativo ayudas didácticas y recomendaciones metodológicas. Todo esto requiere el desarrollo y uso de nuevas tecnologías educativas para formar la actitud valórica de los estudiantes hacia su salud. Debido al brote de COVID-19, los rectores de muchas universidades debieron tomar la difícil decisión de suspender las actividades educativas de sus estudiantes, lo que exige una rápida adaptación a las nuevas condiciones. El estudio tiene como objetivo determinar la preparación de los estudiantes para formar competencias de salud relacionadas con la actividad física en el curso de educación a distancia. El artículo proporciona una evaluación experimental de la preparación de los estudiantes para formar la competencia de salud relacionada con la actividad física en el curso del aprendizaje a distancia. La falta del mismo estipula la necesidad de determinar actividades específicas para mejorar la educación a distancia en educación física y deportes. En consecuencia, la necesidad actual es formar la competencia en salud relacionada con la actividad física de los estudiantes, que asegure la mejora de su salud y la posibilidad de realizar sus potencialidades en el proceso de aprendizaje.

Palabras clave: COVID-19. Competencia en salud relacionada con la actividad física. La educación a distancia. Trabajo independiente.

\section{INTRODUCTION}

Modern life conditions require the solution of an important task of state policy in the field of education, i.e. the formation of a healthy personality (Gadzaova et al., 2021; Gogiberidze et al., 2020). Regarding the main goals of education, preserving and improving the health of students, along with ensuring the appropriate level of their psychophysical readiness for professional activity, 
are the priority tasks of physical education in higher education institutions (Boyarskaya, 2017; Panikarova et al., 2021). In general, the state of students during training is marked by mental fatigue, and, as a consequence, a decrease in psychophysiological resources and the efficiency of the body's functioning (Baronenko, Rapoport, 2010; Afanasiev et al., 2021).

As the psychophysical state of students constantly worsens, it is necessary to create and implement new forms and methods of physical education to ensure the effective implementation of the goals and objectives set (Kuznetsova, 2020; Aleksandrova et al., 2021).

The anti-coronavirus measures have imposed certain restrictions on the full-fledged educational process in universities (Shakhova et al., 2019; Krivova et al., 2021). In this regard, universities try to create favorable conditions to improve the health of their students. The issue is of particular importance due to the decreasing physical activity of students in connection with changes in their usual way of life. In our opinion, this can be a factor in the deterioration of the functional state of students, their physical fitness and physical development. When students spend all their study time only on mental activity, the effective implementation of their physical activityrelated health competence is undermined, which influences the strengthening of immunity and the formation of a well-rounded personality.

In consideration of the foregoing and taking into account the epidemiological situation in Russia, it is urgent to develop positions and directions for introducing innovative approaches in the process of forming the physical activity-related health competence of students, which allows to intensify and bring this process to a new level.

\section{LITERATURE OVERVIEW}

In the field of physical education, scholars view competences as complex and systemic personal beliefs, including motivational and values-based orientations towards a healthy lifestyle (Akishin, 2008); emotional and volitional components that ensure the readiness of future specialists for physical improvement and development with the help of physical fitness and sports (Manzhelei, Chernyakova, 2014); systemic knowledge on physical education and health improvement, subjective experience, skills and abilities for solving physical activity- and health-related issues (Mayorga-Vega et al., 2016).

Many scientific works are concerned with the formation of physical activity-related health competence (Parkhaeva, Ilmushkin, 2018; Dudley et al., 2017; Starodubtsev, 2017) substantiated that the formation of such a competence is among the main tasks of physical education in higher education, which corresponds to the humanistic orientation of general education.

Scholars (Haible et al., 2020; Sudeck, Jeckel, Schubert, 2018; Kozina, 2020) understand physical activity-based health competence as a personal psychological concept aimed at maintaining physical, social, mental, and spiritual health by means of fitness and sports. According to them, such a competence presupposes a set of formed skills that contribute to physical health (physical activity, rational nutrition, sanitary and hygienic skills, work and rest regime) (Manzheley, Cherniakova, 2017) and mental health (self-awareness and self-esteem, problem analysis and decision-making, the determination of life goals and action programs, self-control skills, motivation for success and will training) (Klieme et al., 2008).

R.S. Nagovitsyn and I.V. Ipatov (2012) regarded internal, potential, and latent psychological neoplasms as the physical activity-related health competence: knowledge, motives, preferences, interests, abilities, skills, action programs, a system of values related to physical education and health activities.

Scholars (Cairney et al., 2019; Andryushenko et al., 2004) believe that the formation of the physical activity-related health competence among students should ensure a high level of psychosomatic health and mental performance, as well as motivation for adhering to a healthy lifestyle and fostering a high level of health culture. 
However, there are no studies of students' readiness to form the physical activity-related health competence in distance learning, which confirms the relevance of the chosen research topic.

The study aims at substantiating the theoretical foundations and assessing students' readiness for forming the physical activity-related health competence in distance learning.

The research hypothesis is as follows: the insufficient readiness of students to form the physical activity-related health competence stipulates the need to determine specific activities to improve distance learning in physical education and sports.

According to the above-mentioned objective, we set the following tasks:

1. To experimentally assess the readiness of students to form the physical activity-related health competence in distance learning;

2. To determine specific activities to improve distance learning in physical education and sports.

\section{METHODS}

The experiment was conducted at the Financial University under the Government of the Russian Federation, Saint Petersburg State Maritime Technical University, and Moscow State University of Technology and Management named after K.G. Razumovsky.

In accordance with the study objectives, we selected 172 respondents, including 52 students from the Financial University under the Government of the Russian Federation, 48 students from Saint Petersburg State Maritime Technical University, and 51 students from Moscow State University of Technology and Management named after K.G. Razumovsky. In addition, we questioned 21 scientific and pedagogical workers as experts (departments of physical education).

We developed criteria to assess students' readiness to form the physical activity-related health competence in distance learning: motivational, cognitive, and activity-based.

The motivational criterion of readiness to form the physical activity-related health competence in distance learning can be defined as a system of conscious and personally acquired needs and motives for a healthy lifestyle, the improvement of one's life based on personal selfrealization in the field of fitness and sports, along with professional development. The motivational criterion comprises different levels of readiness for physical education, the desire to constantly improve physical culture, healthcare, and sports skills.

The cognitive criterion of readiness to form the physical activity-related health competence in distance learning is viewed as a system of mastering the theory and methodology of physical education, the practice of organizing and conducting sports events. It develops knowledge, skills, and abilities.

The activity-based criterion of readiness to form the physical activity-related health competence in distance learning is a complex of personally acquired methods to build an individual toolkit of motor skills and abilities necessary in life, and the ability to pass them on to others.

The physical activity-related health competence of students can have high, sufficient, average, and low levels.

A high level of readiness presupposes that a student has an established system of skills and abilities. They actively use the acquired knowledge, skills, and abilities in everyday life, have a strong interest in physical culture, health improvement, and sports activities, systematically engage in physical education and fitness, take an active part in organizing and conducting competitions, know how to select methods and means of physical education for real-life use.

A sufficient level means that the future specialist has an established system of knowledge, abilities, and skills, knows a complex of methods, and fully uses the means of physical education. This student uses knowledge, abilities, and skills in everyday life, has an interest in fitness and health-related activities, systematically engages in physical culture and sports, realizes the need to improve sports skills, and does not need external motivation. 
An average level of readiness demonstrates the formation of certain skills and abilities within the physical activity-related health competence but they do not form a system. The student has an interest in using the acquired knowledge, abilities, and skills in physical culture and health-related activities, systematically engages in fitness, has an interest in developing the mastery of their sport.

Students with a low level of readiness have some skills and abilities but do not fully use the means of physical education. They have only fragmentary ideas in the theory and practice of physical education and sports, need external stimulation for self-education, do not systematically engage in physical exercises and sports.

The main research method was conversation with students and teachers (experts) in the course of distance learning. Conversations with students aimed at clarifying criteria showing their readiness to form the physical activity-related health competence. Conversations with teachers aimed at determining specific directions of forming the physical activity-related health competence of students in the course of distance learning.

\section{RESULTS}

The results of assessing the level of students' readiness for forming the physical activityrelated health competence during distance learning are presented in Table 1.

Table 1. The assessment of students' readiness to form the physical activity-related health competence during distance learning

\begin{tabular}{|c|c|c|c|c|c|c|}
\hline \multirow[t]{2}{*}{ No. } & \multirow[t]{2}{*}{ Criterion } & \multirow[t]{2}{*}{ Groups } & \multicolumn{4}{|c|}{ Development levels, in \% } \\
\hline & & & Low & Average & Sufficient & High \\
\hline \multirow[t]{3}{*}{1} & \multirow[t]{3}{*}{ Motivational } & $\begin{array}{l}\text { Financial University under the Government of the Russian } \\
\text { Federation }\end{array}$ & 45.6 & 29.1 & 17.8 & 7.5 \\
\hline & & Saint Petersburg State Maritime Technical University & 48.1 & 30.6 & 16.6 & 7.2 \\
\hline & & Moscow State University of Technology and Management & 46.3 & 31.8 & 13.6 & 8.3 \\
\hline \multirow[t]{3}{*}{2} & \multirow[t]{3}{*}{ Cognitive } & $\begin{array}{l}\text { Financial University under the Government of the Russian } \\
\text { Federation }\end{array}$ & 38.2 & 39.5 & 14.9 & 6.8 \\
\hline & & Saint Petersburg State Maritime Technical University & 36.6 & 40.1 & 15.9 & 7.4 \\
\hline & & Moscow State University of Technology and Management & 37.8 & 38.4 & 16.6 & 7.2 \\
\hline \multirow[t]{3}{*}{3} & \multirow[t]{3}{*}{$\begin{array}{l}\text { Activity- } \\
\text { based }\end{array}$} & $\begin{array}{l}\text { Financial University under the Government of the Russian } \\
\text { Federation }\end{array}$ & 45.1 & 27.8 & 19.2 & 6.9 \\
\hline & & Saint Petersburg State Maritime Technical University & 43.7 & 28.3 & 22.2 & 5.8 \\
\hline & & Moscow State University of Technology and Management & 44.9 & 30.5 & 18.4 & 6.2 \\
\hline
\end{tabular}

The results of assessing the motivational criterion have revealed that most students have low (Financial University under the Government of the Russian Federation - 46.7\%, Saint Petersburg State Maritime Technical University - 48.1\%, Moscow State University of Technology and Management $-46.3 \%$ ) or average levels (Financial University under the Government of the Russian Federation - 29.1\%, Saint Petersburg State Maritime Technical University - 30.6\%, Moscow State University of Technology and Management $-31.8 \%$ ) of readiness to form the physical activityrelated health competence.

The monitoring of the cognitive criterion during distance learning has proved that most students have average (Financial University under the Government of the Russian Federation 39.5\%, Saint Petersburg State Maritime Technical University $-40.1 \%$, Moscow State University of Technology and Management $-38.4 \%$ ) or low (Financial University under the Government of the Russian Federation - 38.2\%, Saint Petersburg State Maritime Technical University - 36.6\%, Moscow State University of Technology and Management - 37.8\%) levels of knowledge and skills regarding their readiness to form the physical activity-related health competence.

The study of the activity-based criterion has brought similar results to those of assessing the motivational criterion. Regarding readiness to form the physical activity-related health competence, most students have low (Financial University under the Government of the Russian Federation - 
45.1\%, Saint Petersburg State Maritime Technical University - 43.7\%, Moscow State University of Technology and Management -44.9\%) and average (Financial University under the Government of the Russian Federation - 27.8\%, Saint Petersburg State Maritime Technical University - 28.3\%, Moscow State University of Technology and Management - 30.5\%) levels of mastering special knowledge, abilities, and skills to control physical fitness and health, properly apply the means and methods of physical education for developing one's physical qualities in the process of life.

\section{DISCUSSION}

In the course of the study, we revealed some problems in relation to students' readiness to form the physical activity-related health competence during distance learning:

- No motivation of students to form the physical activity-related health competence, and their need for external stimulation in the context of self-education;

- Fragmentary ideas in the theory and practice of physical education and sports, inconsistent skills and abilities in the field of physical culture and health-related activity;

- The lack of systemic exercises and sports activities.

Based on the conversations with students, we questioned their teachers (experts) regarding the necessary activities to improve the organization of distance learning in the sphere of physical education and sports under the conditions of quarantine restrictions.

These conversations with teachers have revealed that the organization of distance learning in the sphere of physical education and sports under the conditions of quarantine restrictions can be improved based on specific activities.

The experts noted that students should not stop exercising during the quarantine. In this case, the conscious and independent work of students becomes crucial. At the same time, the educational process is maintained through the functioning of distance learning environments (Kozina, 2020).

Digital technologies allow introducing new practices. Consequently, it is worth mentioning (Nagovitsyn, Ipatov, 2012) that innovative activity is embodied in the development and implementation of new technologies aimed at forming the physical activity-related health competence of students. The creation of such means presents the pedagogical and scientific aspects of students applying health-related methods during the quarantine. Thus, the opportunity is realized to form students' knowledge, skills, and abilities to manage individual health. In general, the experts agree with the opinion (Akilov, 2000; Kuznetsova, 2020) that maintaining an appropriate level of physical activity-related health competence is necessary to prevent physical and mental health disorders.

Under quarantine restrictions, the experts noted that independent work became the main form of organizing the educational process. Its role increased so much that it is now necessary to plan and create special forms, methods, and teaching aids. Intensive computerization requires the reorganization of the educational process and the wider use of innovative teaching aids, one of which is new means of methodological and didactic support of the physical education of students, i.e. educational and methodological e-complexes (Sedov, Krasnova, Kulish, 2020) based on the achievements of the programmed teaching approach and computerization in physical education.

The experts identified the advantages of using distance learning tools for acquiring the physical activity-related health competence by students: interactivity, intensification, and feedback. With the help of distance learning tools, students have constant access to educational materials, i.e. they can view them at any time and use them for their independent work (Starodubtsev, 2018).

The experts emphasized that the use of educational and methodological e-complexes could form the physical activity-related health competence of students and keep it at an appropriate level during the coronavirus pandemic. It is manifested in the student's ability to apply the acquired skills of a careful attitude to their health in a specific situation, i.e. the suspension of educational activity. 
This should neutralize the harmful effects of forced restrictions when gyms and stadiums, swimming pools and dance studios are closed due to the COVID-19 pandemic. However, physical fitness can be possible even during quarantine thanks to the physical activity-related health competence.

According to the results of the expert survey, the formation of the physical activity-related health competence of students by means of distance learning in the process of their physical education includes as follows:

- The student's ability to use information technologies and the corresponding teaching tools;

- Health education technologies: hygienic education, the formation of life skills (emotion management, conflict resolution, etc.), substance misuse and injury prevention;

- Recreational technologies: to strengthen the physical health of students, increase their health resources (physical or cold training, music therapy, physical exercises, i.e. everything that helps to counteract stress and feel psychological comfort at the level of physiology (Kuznetsova, 2020));

- Culture of health: personality traits that contribute to the preservation and strengthening of health, the formation of a values-based attitude towards health, increased motivation to lead a healthy lifestyle, and more responsibility for personal health.

The experts believed that the effective formation of the physical activity-related health competence of students in the context of restrictions depended on how students positioned themselves and what benefits they saw for themselves. They claimed that the introduction of distance learning, as a new environment in physical education, could solve the following pressing issues:

- To consider individual psychological characteristics (perception, memory, thinking) and the individual time perception of educational material;

- To create graphic recommendations (video guides) on how to organize the physical activity of students at home during the quarantine;

- To ensure an individual approach during classes;

- To provide a large amount of information and use it based on the person-centered approach;

- To present information in the form of a completed task;

- To allow students to monitor their personal development, predict possible changes in health and take appropriate psychological, pedagogical, corrective, rehabilitation measures to maintain good health.

All the things considered, the experts emphasized that the introduction of distance learning technologies into the process of forming the physical activity-related health competence should focus on personality development. According to (Haible et al., 2020), it is necessary to personalize the formation of this competence among students. In the process, it is recommended to develop students' interests, form their skills and abilities, and promote the related valeological knowledge.

To achieve a positive result in forming the physical activity-related health competence by means of distance learning, complementarity should be ensured. At the same time, it is necessary to create conditions for satisfying basic physiological needs, and especially the self-actualization of students, since the psychological mechanism of physical activation during social self-isolation will help an individual endure the imposed restrictions. Thus, a person focuses exclusively on what is under their direct control. On a mental level, physical exercises improve mood, planning, and decision-making, reduce anxiety and stress, and increase self-esteem.

While forming the physical activity-related health competence of students, it is necessary to monitor the influence of distance learning tools on physical education. At the same time, the subject of monitoring is the dynamics of the physical, mental, social, spiritual, and moral health of students. Thus, Klieme, Hartig, Rauch (2008) substantiated that motivation and awareness of the need to 
improve one's physical and emotional state is a driving factor in the formation of physical activityrelated health competence.

\section{CONCLUSION}

The formation of the physical activity-related health competence among students should promote physical self-improvement, systemic training, a responsible and competent attitude towards health, the development of healthy values, which will determine their behavior based on motivation to strengthen health under the conditions of forced physical inactivity.

The research results have confirmed the hypothesis that the insufficient readiness of students to form the physical activity-related health competence stipulates the need to determine specific activities to improve the organization of distance learning in physical education and sports. Under the conditions of forced self-isolation, education aims at creating sustainable motivation for a healthy lifestyle, forming the need for physical self-improvement to update the content of physical education, building a new educational environment, introducing new forms and methods of organizing this process by means of distance learning. The latter is regarded as a modern educational environment, comfortable, safe, and convenient for all participants in physical education, with the potential to ensure the effectiveness of this process.

Further scientific research should focus on the development of new methods for forming the physical activity-related health competence of students in distance learning.

Authors' Contributions: Mokrova, L. P.: conception and design, acquisition of data, analysis and interpretation of data, drafting the article, critical review of important intellectual content. Evografova, I. V.: conception and design, acquisition of data, analysis and interpretation of data, drafting the article, critical review of important intellectual content. Boadanova, T. V.: conception and design, acquisition of data, analysis and interpretation of data, drafting the article, critical review of important intellectual content. Vakulenko, A.: conception and design, acquisition of data, analysis and interpretation of data, drafting the article, critical review of important intellectual content. Konnova, O. A.: conception and design, acquisition of data, analysis and interpretation of data, drafting the article, critical review of important intellectual content. All authors have read and approved the final version of the manuscript".

Ethics Approval: Not applicable.

Acknowledgments: Not applicable.

\section{REFERENCES}

Afanasiev, I.V., Vysotskaya, N.V., Alferov, V.N., Grigorieva, N.A. (2021). The use of cloud resources and services in distance learning of students in the context of restrictions caused by the pandemic. Revista Tempos e Espaços em Educação, 14(33), e16103. https://doi.org/10.20952/revtee.v14i33.16103

Akilov, M.V. (2000). Individualnyi stil zdorovogo obraza zhizni tsel obucheniya v sisteme fizkulturnogo obrazovaniya [An individual healthy lifestyle as an objective of physical education]. Fizicheskaya kultura: vospitanie, obrazovanie, trenirovka, 2, 10-11.

Akishin, B.A. (2008). Formirovanie u studentov motivatsionno-tsennostnogo otnosheniya k fizicheskoi culture [Forming the motivational and values-based attitude of students towards physical education]. Teoriya i praktika fizicheskoi kultury, 12, 77-79.

Aleksandrova, I.B., Vorobyova, K.I., Gileva, N.V., Livson, M., Cheprasova, T.V., Bazhin, G.M. (2021). Influence of digital assistive technologies used in higher education on the development of individual educational strategies among students with disabilities. International Journal of Early Childhood Special Education, 13(2), 1146-1153.

https://doi.org/10.9756/INT-JECSE/V13I2.211160

Andryushenko, L.B., Loseva, I.V., Orlan, I.V. (2004). Upravlenie protsessom sportivnykh i ozdorovitelnykh tekhnologii v uchebnyi protsess fizkulturnogo obrazovaniya studentov [Managing sports- and health-related technologies in the physical education of students]. Teoriya i praktika fizicheskoi kultury, 11, 44-48.

Baronenko, V.A., Rapoport, L.A. (2010). Zdorove i fizicheskaya kultura studenta [The health and physical fitness of students]: Student's textbook. Moscow: Alfa-M: INFRA-M. 
Boyarskaya, L.A. (2017). Metodika i organizatsiya fizkulturno-ozdorovitelnoi raboty [The methodology and organization of health and fitness activities]: Student's textbook. Yekaterinburg: Izd-vo Ural. un-ta.

Cairney, J., Dudley, D., Kwan, M., Bulten, R., Kriellaars, D. (2019). Physical literacy, physical activity and health: Toward an evidence-informed conceptual model. Sports Medicine, 49(3), 371-383. https://doi.org/0.1007/s40279-019-010633

Dudley, D., Cairney, J., Wainwright, N., Kriellaars, D., Mitchell, D. (2017). Critical considerations for physical literacy policy in public health, recreation, sport, and education agencies. Quest, 69, 436-452.

Gadzaova, L.P., Goverdovskaya, E.V., Alisultanova, E.D., Moiseenko, N.A. (2021). Organized Online Learning of Students in Universities and Schools: Didactics and Methodology. Propósitos y Representaciones, 9(3), 1181. http://dx.doi.org/10.20511/pyr2021.v9nSPE3.1181

Gogiberidze, G.M., Isakov, V.A., Ershova, T.V., Shulgina, O.V. (2020). Development of innovations in the educational environment: inclusive education and digital technologies. Revista Inclusiones, 7, 147-158.

Haible, S., Volk, C., Demetriou, Y., Höner, O., Thiel, A., Sudeck, G. (2020). Physical Activity-Related Health Competence, Physical Activity, and Physical Fitness: Analysis of Control Competence for the Self-Directed Exercise of Adolescents. International Journal of Environmental Research and Public Health, 17(1), 39. https://doi.org/10.3390/ijerph17010039

Klieme, E., Hartig, J., Rauch, D. (2008). The concept of competence in educational contexts. Assessment of competencies in educational contexts, in: Hartig, J., Klieme, E., Leutner, D. Hogrefe (eds.). Göttingen: Publishing $\mathrm{GmbH}$.

Kozina, Zh.G. (2020). Distantsionnaya fizicheskaya kultura: mif ili realnost [Distance physical education: myth or reality]. Kaliningradskii vestnik obrazovaniya, 2(6), 28-34.

Krivova, A.L., Kalliopin, A.K., Korotaeva, I.E., Shafazhinskaya, N.E., Ermilova, D.Y. (2021). Social networks as a means of monitoring students' progress. Propósitos y Representaciones, 9(3), 1264.

http://dx.doi.org/10.20511/pyr2021.v9nSPE3.1264

Kuznetsova, A.S. (2020). Fizkulturno-ozdorovitelnye tekhnologii v ukreplenii sostoyaniya zdorovya studentov [Health and fitness technologies for improving students' health]. Izvestiya rossiiskoi voenno-meditsinskoi akademii, 39(2), 140141.

Manzhelei, I.V., Chernyakova, S.N. (2014). Formirovanie fizkulturnykh kompetentsii u bakalavrov v obrazovate'noi srede vuza [Forming athletic competences of bachelor students in the university environment]. Vestnik Tyumenskogo gosudarstvennogo universiteta. Pedagogika. Psikhologiya, 9, 78-91.

Manzheley, I.V., Cherniakova, S.N. (2017). Development of Bachelor's Physical Culture Competences. Journal of Siberian Federal University. Humanities \& Social Sciences, 7, 1204-1215.

Mayorga-Vega, D., Montoro-Escaño, J., Merino-Marban, R., Viciana, J. (2016). Effects of a physical education-based programme on health-related physical fitness and its maintenance in high school students: A cluster-randomized controlled trial. European Physical Education Review, 22, 243-259.

Nagovitsyn, R.S., Ipatov, I.V. (2012). Formirovanie innovatsionnoi fizkulturno-ozdorovitelnoi kompetentnosti budushchikh spetsialistov [Forming the innovative athletic and recreational competence of future specialists]. Vestnik Kazanskogo tekhnologicheskogo universitetayu, 15, 20.

Panikarova, N.P., Dzhamirze, N.K., Skorodumova, O.B., Musaeva, K.M., Konovalova, E.E. (2021). The influence of formative assessment of students' academic achievements on increasing their motivation to study at university. Revista EntreLinguas, 7(4), 15636. https://doi.org/10.29051/el.v7iesp.4.15636.

Parkhaeva, O.V., Ilmushkin, G.M. (2018). Formirovanie fizkulturno-ozdorovitelnoi kompetentnosti budushchikh spetsialistov atomnoi otrasli [Forming the athletic and recreational competences of future nuclear specialists]. Teoriya i praktika fizicheskoi kultury i sporta, 963(9), 26-29.

Sedov, I.A., Krasnova, D.S., Kulish, D.S. (2020). Organizatsiya novykh formatov fizkulturno-ozdorovitelnoi deyatelnosti v usloviyakh sokhraneniya riskov rasprostraneniya pandemii [Creating new forms of physical and health-related activities in the context of persisting risks connected with the pandemic]. Pedagogika, psikhologiya, obshchestvo: aktualnye voprosy: proceedings of the All-Russian and International scientific conference. Cheboksary: ID "Sreda".

Shakhova, M.S., Smorodinova, M.V., Repushevskaya, O.A., Tkach, A.V., Balalova, E.I., Saydulaev, D.D. (2019). Digital education in the context of the development of the digital economy: technological opportunities and prospects. International Journal of Innovative Technology and Exploring Engineering (IJITEE), 9(1), 3972-3976. 
Starodubtsev, M.P. (2017). Kompetentnostnyi podkhod k realizatsii samostoyatelnoi raboty studentov [The competence-based approach to the independent work of students]. Uchenye zapiski universiteta im. P.F. Lesgafta, 12(154), 271-275.

Starodubtsev, M.P. (2018). Osnovy metodiki samostoyatelnykh zanyatii fizicheskimi uprazhneniyami [The general methods of individual physical exercises]. Tendentsii razvitiya nauki i obrazovaniya, 45(4), 73-79.

Sudeck, G., Jeckel, S., Schubert, T. (2018). Individual differences in the competence for physical-activity-related affect regulation average the activity-affect association in real-life situations. The Journal of Sport \& Exercise Psychology, 40, 196-205.

Received: 31 September 2021 | Accepted: 12 January 2022 | Published: 20 February 2022

This is an Open Access article distributed under the terms of the Creative Commons Attribution License, which permits unrestricted use, distribution, and reproduction in any medium, provided the original work is properly cited. 